DOI: 10.2478/tperj-2013-0019

\title{
Study Regarding the Play of the wing player at the World Handball Championship - Serbia 2013
}

\section{Ionică CĂRĂBAȘ ${ }^{1}$}

\section{Abstract}

The ascension to the top of the world hierachy in hanball implies a minutiously preparation, considering all the factors of the sporting training, of the players who compose the team. If, not long ago, a team having a $9 \mathrm{~m}$ line and a valuable goalkeeper could lean the victory balance in its favour, nowadays, a team can not win a high level competition without having very valuable players on the other posts too. Considering the aspects presented, the study proposes to demonstrate the importance of the players' contribution who evolve on the wing post, in the modern handball game.

Key words: handball, wing player, model.

\section{Rezumat}

Accederea spre vârful ierarhiei mondiale în handbal implică o pregătire minuțioasă, prin prisma tuturor factorilor antrenamentului sportiv, a jucătoarelor componente ale unei echipe. Dacă până nu de mult, o echipă care avea o linie de $9 \mathrm{~m}$ și un portar de valoare putea înclina balanța victoriei în favoarea sa, astăzi o echipă nu poate câștiga o competiție de nivel înalt fără a avea jucători de mare valoare și pe celelalte posturi. Având în vedere aspectele prezentate, studiul își propune să demonstreze importanța aportului jucătoarelor care evoluează pe postul de extremă, în jocul de handbal modern.

Cuvinte cheie: handbal, extremă, model.

\footnotetext{
${ }^{1}$ Lecturer, PhD, West University of Timișoara, Faculty of Physical Education and Sports, e-mail: i.carabas@yahoo.com
} 


\section{Introduction}

In the last years the defences more and more compact and agressive. Finding the solutions to anihilate the actions of the palyers who evolve at the $9 \mathrm{~m}$ level line and of the pivots, has determined the alloting of a special attention to the training of the players posted in side zones of the pitch.

The big international competitions show that the eficiency of the throwing to the goalpost from the outside has considerably increased. It should also be mentioned that most of the wing players come to the sorrounding and throw from 9-10 m, entering and acting as a real inter.

The wing players have also improved the game without a ball, especially entering in the space between the side, intermediate or central defenders, remaining as a priority for the outsiders, the task of solving the direct counterattack and the active participation to the rapid attack.

\section{Contents}

The wing player in handball, as in other sports, has a technical - tactical content very well defined, both on the attack phase and on the defence phase. In the present work, we will study only aspects linked to the attack phase.

The game tasks of the wing player are the following:

- Every time when the opponent loses the ball, she should proceed to the attack in the highest speed, even if this is not passed to her;

- If she does not receive the ball, she stops at the 9m line level, as near as possible to the touchline;

- Enters the semicircle if the side defender has not retreated or has come out to the back player on her side, when the defence is unorganized or the temporary zone is much advanced;

- In the phase of game organizing, she stands largely on the outer part, and in the attack with subsequent passes she initiates the entering, threatens between the first two defenders and she passes rapidly;

- In the attack in circulation, she enters among the defenders up to the central zone, sometimes beyond this, temporary changing herself in a pivot, performing screns and blockings for the $9 \mathrm{~m}$ line and for the pivot, eventually finalizing from this post with specific procedures;

- On the post she has a permanent tendency to act offensively, planning outrunnings and continually pressing the side defender;

- In the situation of ,one to one,, in a favourable angle, she performs determined the outrunning of the opponent, or to the inner part, or to the outer part;

- Finalizes, generally with jumping punge, increasing as much as possible, the angle towards the centre of the semicircle;

- She should well know and perform the following tactical combinations:

- simple and double screen with the pivot, for the back player on her side or that on the opposite;

- all the combinations in triangle on the outside, with the pivot and the inter on her side;

- at least 2-3 combinations in two with the inter, the pivot and the centre.

- The valuable outsiders know and perform very well, beside the so called classical throwing procedures, specific procedures too:

- the throwing with a very big increasing of the angle and landing on the kicking foot;

- the throwings with vault over the goalkeeper;

- the throwings with the earth and rounding effect;

- the lifted throwings ;

- the aerial throwings (the catching and the throwing from jump from over the semicircle)[1].

From the physical point of view, the wing players must posses, besides force and resistance, speed 
and skill superior than the players on the other posts.

- During the running period of the World Championship, 27 players belonging to the teams situated on the first 8 positions in the final hierarchy of the competition were analized, in order to establish their contribution to the obtaining of the team results [2].

\section{Results}

Analyzing from the somatic point of view the 27 players, I have noted waists with values ranged between 162 and $178 \mathrm{~cm}$, with an average of 170.6 cm [3]. Their weight varies between 52 and 69 kilos, with an average of 63.8 kilos. The age average of the players is 27.4 years old (Table I).

Table l. The somatic point of view of the 27 wing players

\begin{tabular}{lccccc}
\hline \multicolumn{1}{c}{ Name } & Team & Position & Height & Weight & Age \\
\hline Nascimento A & Brazil & RW & 177 & 67 & 32 \\
Rocha S. & Brazil & LW & 170 & 65 & 24 \\
Da silva F. & Brazil & LW & 176 & 68 & 24 \\
Costa M. & Brazil & RW & 166 & 64 & 21 \\
Krpez K. & Serbia & RW & 167 & 67 & 25 \\
Ognjenovic S. & Serbia & LW & 168 & 60 & 32 \\
Nisavic J. & Serbia & LW & 168 & 61 & 33 \\
Milosevic I. & Serbia & RW & 168 & 62 & 31 \\
Fisker M. & Denmark & LW & 170 & 67 & 23 \\
Nørgaard A. G & Denmark & LW & 162 & 60 & 30 \\
Østergaard T. & Denmark & RW & 165 & 60 & 22 \\
Grzyb K. & Poland & LW & 168 & 58 & 31 \\
Koniuszaniec & Poland & RW & 177 & 69 & 28 \\
Migala M. & Poland & RW & 168 & 60 & 26 \\
Jochymek A. & Poland & LW & 170 & 63 & 28 \\
Riegelhuth- L.K & Norway & RW & 175 & 67 & 29 \\
Herrem C. & Norway & LW & 169 & 63 & 27 \\
Solberg S. & Norway & LW & 178 & 69 & 23 \\
Budouin P. & France & LW & 172 & 58 & 29 \\
Tounkara M. & France & RW & 164 & 52 & 30 \\
Dembele S. & France & LW & 172 & 64 & 27 \\
Deroin A. & France & RW & 176 & 69 & 24 \\
Zapf M. & Germany & RW & 170 & 63 & 23 \\
Augsburg N. & Germany & LW & 175 & 69 & 30 \\
Verten O. & Hungary & LW & 170 & 69 & 31 \\
Bognar-Bodi B. & Hungary & RW & 175 & 64 & 27 \\
Kovacsicz M. & Hungary & RW & 171 & 66 & 30 \\
\hline & & & & & \\
\hline & & & &
\end{tabular}

From the number of goals scored point of view [3], it could be observed that from a total of 1768 goals, the outsiders scored a number of 249 , which represent a percent of $14.05 \%$. The least percentage was performed by the Serbian team (10\%) and the biggest by the Hungarian team (16.84\%) (table II).

Table II. The number of goals scored point of view

\begin{tabular}{lccl}
\hline Team & $\begin{array}{c}\text { Total no. of } \\
\text { goals } \\
\text { scored of } \\
\text { the team }\end{array}$ & $\begin{array}{c}\text { Total no. of } \\
\text { goals scored } \\
\text { from the wing } \\
\text { players }\end{array}$ & Percentage \\
\hline Brazilia & 253 & 42 & 16.6 \\
Serbia & 240 & 24 & 10 \\
Danemarca & 255 & 38 & 14.91 \\
Polonia & 238 & 33 & 13.87 \\
Norvegia & 198 & 26 & 13.14 \\
France & 173 & 21 & 12.14 \\
Germany & 209 & 31 & 14.84 \\
Hungary & 202 & 34 & 16.84 \\
\hline
\end{tabular}

Analyzing the evolution of the wing players of each team, we conclede that the Hungarian team has the best percent (61.87\%), followed by the Denmark (61.2\%), Norway (59\%), Germany (55.36\%), Brazil (55.2\%), France (53.8\%), Poland (51.57\%) and Serbia (48\%) (Table III).

Table III. Evolution of the wing players

\begin{tabular}{lcccccl}
\hline Team & Goals & Saves & Missed & Post & Total & Percentage \\
\hline Brazilia & 42 & 16 & 6 & 12 & 76 & 52.2 \\
Serbia & 24 & 22 & 3 & 1 & 50 & 48 \\
Danemarca & 38 & 16 & 5 & 3 & 62 & 61.2 \\
Polonia & 33 & 18 & 6 & 7 & 64 & 51.57 \\
Norvegia & 26 & 10 & 4 & 4 & 44 & 59 \\
France & 21 & 11 & 4 & 3 & 39 & 53.8 \\
Germany & 31 & 15 & 4 & 6 & 56 & 55.36 \\
Hungary & 34 & 12 & 6 & 3 & 55 & 61.87 \\
\hline
\end{tabular}

The wing players have also an important contribution in the finalizing of the throwings from $7 \mathrm{~m}$, too, the success being a very good one (75.4\%) (Table IV).

Table IV. Contribution of the wing players in the finalizing of the throwings from $7 \mathrm{~m}$

\begin{tabular}{llll}
\hline Team & Wing player & $\begin{array}{l}\mathbf{7 m} \\
\text { scored/shots }\end{array}$ & Percentage \\
\hline Brazilia & Nascimento A. & $23 / 29$ & $79,31 \%$ \\
Serbia & Ognjenovic S. & $2 / 3$ & $66,67 \%$ \\
Norvegia & Nørgaard G. & $11 / 16$ & $68,75 \%$ \\
France & Baudouin P. & $10 / 13$ & $76,93 \%$ \\
\hline
\end{tabular}

The right wing of the Brasilian National Team, Alexandra Nascimento, was positioned the second in the top of the scorers at this final tournament, with a total of 54 goals. 
In the ideal team of the competition, on the outsider post were nominated Fisker Maria(Denmark) and WOO Sun Hee(Korea) (figure 1).

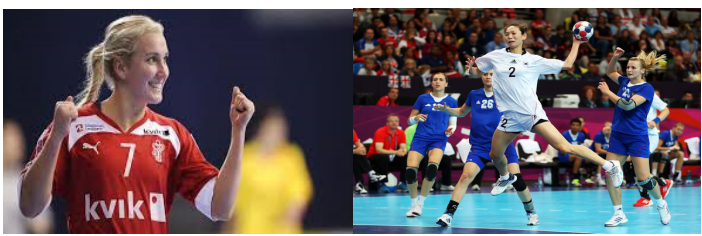

Figure 1. Maria Fisker and Hee Sun Woo [4,5]

\section{Conclusions}

Following the performed study, we can conclude that the contribution of the outsider in the actual handball game has become a determinant one. Despite of the difficulties specific to the post, all the analyzed teams have a success percent at the throwings from outside over 50\%, excepting Serbia which is very close too (48\%). All the top teams have in their structure outsiders of a great value, such as :
Riegelhuth, Herrem, Verten, Baudouin, Norgaard or Nascimento being known to the handball lovers from the whole world. The throwings from $7 \mathrm{~m}$ represent a chapter at which the outsiders cope very well too. It comes as an imperative necesity, that all the trainers, beginning with the minihandball up to the representative lots to consider the trends of the handball game modernization in their thought and methodical concept.

\section{References}

1. Heiner Brand, Handball - Mein Spiel, mein Stil, Philippka Verlag, Deutschland, pp. 67-68;

2. Kunst-Ghermănescu I., Gogâltan V., Jianu E., Negulescu I. Teoria şi metodica handbalului, pag. 87- 89,E.D.P., Bucureşti, 1983, pp. 87-89;

3. http://www.inf.info/, accessed in 11th of November 2013;

4.https://www.google.ro/\#q=maria+fisker, accessed in $11^{\text {th }}$ of November 2013;

5. https://www.google.ro/\#q=hee+sun+woo, accessed in $11^{\text {th }}$ of November 2013 